наук : 12.00 .08 / Дніпропетр. держ. ун-т внутр. справ. Дніпропетровськ, 2007. 258 арк.

8. Шиндель Ю. І. Зміст надання публічних послуг у складі злочину, передбаченому ст. 365-2 КК України // Вісн. Харк. нац. ун-ту ім. В. Н. Каразіна. Сер. : Право. 2013. № 1082. С. 173-177.

9. Яковлева А. М. Сучасний тлумачний словник української мови : 55000 слів. Харків : Торсінг, 2017. 672 с.

DOI https://doi.org/10.30525/978-9934-26-074-2-58

\title{
DEVELOPMENT OF SURVEILLANCE TECHNOLOGIES AS A FACTOR OF COMBATING CRIME BY COLLECTING INFORMATION OF PRIVATE CHARACTER
}

\author{
Khlopov A. A. \\ Postgraduate Student \\ Kharkiv National University of Internal Affairs \\ Kharkiv, Ukraine
}

In the modern world, technology has become an integral part of the life of mankind. This made it possible to redistribute some of the complex tasks for a person to perform on equipment, thereby saving time and effort. From purely pragmatic motives, the automation of production has created the prerequisites for rapid socio-economic development in the world and an increase in the well-being of the population in many regions. In parallel with this, a significant part of the technology is used to perform socially useful tasks, such as ensuring public safety and law and order. First of all, this applies to various camera-fixing devices, which have become widespread and are actively used to improve the law enforcement system and prevent the commission of crimes. However, as a result of their work, various kinds of information of private character are fixed, which leads to the disclosure of the sphere of his private life by the aspect. This creates additional risks of an attack on the rights and freedoms of citizens, as well as abuse by the competent authorities of the state. Therefore, the problem of using surveillance devices and analyzing their impact on privacy looks especially relevant today.

In general, the technological evolution of tracking devices has occurred in a relatively short period of time. The development of the project for the first video surveillance system is attributed to the German engineer Walter Bruch, which was later installed by Siemens in 1942. to monitor the testing of V-2 missiles $(1$, p. 60). In the future, such systems were actively used in testing 
various kinds of rockets and launch vehicles in space programs of interested crane. However, gradually the range of applications expanded and shifted to the niche of the law enforcement and security sector. 1956-1960. In Germany, a system of street cameras is gradually starting to be put into operation to monitor urban traffic, and subsequently to detect violations of traffic rules and observe public assemblies. Subsequently, the idea was adopted by the London police, who in July 1960. installed two temporary cameras in Trafalgar Square to monitor the gathering during an official visit by the Thai royal family. A year later, the capital's railway station was equipped with a similar video surveillance system. Over the next years, such systems began to be actively used in public places to counter vandalism and were implemented on a commercial basis to reduce the level of theft in the retail sector (2). In addition to Europe, overseas began to take an interest in technological innovations in the field of observation. In the United States of America (hereinafter - the USA), the first deployment of video cameras for the purpose of combating crime began from the main street of Olean, New York in 1968. Several installed devices transmitted images to the local police station for 24 hours [1, p. 60]. Subsequently, such systems began to be mastered in various fields; in particular, cameras began to be placed on the buildings of local municipalities, in the premises of banks, and subsequently in shops. Given their rarity and size, it is fair to say that they are performing a certain preventive function. On the other hand, the possibility of fixing made it possible to identify illegal actions and helped to establish the identity of the offender, providing the formation of an evidence base for the investigating authorities.

As a result, over the past 79 years, humanity has made a significant leap towards the evolution of tracking devices, which are not perceived as something new today. Subsequently, this technique gained the ability to instantly identify a person's personality, which actually constitutes the problem. Since from that moment it became possible to collect precisely personalized information of private character about a particular citizen, and not to accumulate information about civil society without reference to its individual individuals. In parallel with this, the increase in the number of installed surveillance systems has created the risks of unjustified interference in the sphere of private life of a person and excessive control over society by governments. After all, all the functionality of this technique is aimed at fixing, processing, storing and transferring various kinds of information of a private nature concerning an individual. The People's Republic of China (hereinafter - PRC) holds the palm in the development of these technologies. In addition, significant progress has been made by specialists from India, The Russian Federation, The USA and a number of European countries (The Federal Republic of Germany, Great Britain, etc.). The reasons for this combination of circumstances are different. For example, in India it is 224 
associated with the formation of a middle class stratum, which, in search of security, creates a request for a reduction in the crime rate. In the Russian Federation, this is due to the need to ensure public order and counter terrorist threats. That is, in each specific case, the spread of identification technologies is dictated by its own challenges facing the respective country and not necessarily related to the fight against crime.

Today, out of twenty cities in the world that have the largest network of cameras, eighteen are located in the PRC. The other two are London and Hyderabad. The first one takes the third position in the ranking and is the only city that is not located in Asia, and the second is one of the centers of high technologies in India (3). In PRC, one of the impetuses for the development of face recognition technologies was the street protests in Hong Kong in 2014. Then, the law enforcement system faced the problem of identifying the protesters, which was difficult in the conditions of smoke and the use of various means of disguise by the protesters. Since then, surveillance and identification technologies in the country have reached a new level. By the end of 2021, BBC news reports with reference to the Wall Street Journal in the PRC, about 560 million surveillance cameras will be installed; in terms of the country's population it will mean one device for 2.4 people. It is noteworthy that according to the publication for 2018 there were only 350 million of these cameras in the country, or one per 4.1 people. At the same time, similar indicators in the USA were at the level of 4.6; UK - 5.6 and 7.1 in Singapore. It is predicted that by the end of 2021 the global number of surveillance cameras will exceed 1 billion (4). At the same time, the results of research carried out by specialists in this area show that the correlation between the number of cameras and a decrease in crime rates is minimal, and the creation of a significant network of surveillance cameras does not always lead to a decrease in the crime rate (3).

If we count the number of cameras in relation to the population of the Earth, then there is a significant increase in the presence of surveillance cameras in our life. In 2018 there were 11.6 people per cell. At the same time the same indicator by the end of 2021 will be about 7.7. If such growth rates are maintained, in 10-15 years we can talk about equalizing the number of surveillance cameras to the world's population. That is, the risks of unjustified interference in the private sphere of human life and control by the government due to the expansion of the network of surveillance devices will only increase. It seems that these risks will be too high compared to the potential effect of such policies in the field of law enforcement, security and prevention of delinquency in society.

Conclusions:

Summing up, we can confidently assert that observation technologies have reliably entered the life of mankind. The indicated situation will only get worse over time, because these technologies allow not only maintaining law 
and order, but also allowing solving a number of other acute problems today. For example, compliance with quarantine restrictions and social distance in a pandemic, countering the growing level of terrorist threats and other challenges.

That said this study shows that the focus on motivating the diffusion of such technologies has changed over time. The first installed devices recorded illegal actions and stored information that could be considered as evidence in the future. However, today, the active expansion of the coverage area has significantly quantitatively affected the benefits obtained. As a result, there has been an increase in the scope and volume of information received, including of private character. This led to a departure from the solution of single tasks at the local level to the implementation of a set of measures within the coverage system.

At the same time, based on open data and research carried out by specialists in this field, we can say that today the correlation between the number of installed cameras and the level of crime is minimal. That is, the effectiveness of combating crime does not lie exclusively in the plane of the continuous placement of cameras to the extent that it might seem at first glance. However, in some areas, surveillance systems have proven to be uncontested. For example, this concerns the issues of fixing traffic violations. Otherwise, the situation looks in such a way that the amount of information that is recorded, processed and stored creates disproportionately large risks for the sphere of a person private life. In this case, part of the information of private character falls into the use of the competent authorities without the will of the person. In fact, to date, surveillance technology does not seem to be a key factor in the possible formation of an effective criminal law policy for combating crime at the state level around it.

\section{References:}

1. Ogunyinka , O., Soyemi, J. and Soyemi, O.B. 2011. Security Surveillance Architecture: The Wireless Mesh Network Approach. Mediterranean Journal of Social Sciences. 2, 6 (Nov. 2011), P. 59-65.

2. Video Surveillance Systems. The History. URL http://info300.net/ fmwangi/Brief1.html

3. Surveillance camera statistics: which cities have the most CCTV cameras? VPN \& Privacy. Blog. URL: https://www.comparitech.com/vpnprivacy/the-worlds-most-surveilled-cities/

4. The US, like China, has about one surveillance camera for every four people, says report. URL: https://www.theverge.com/2019/12/9/ 21002515/surveillance-cameras-globally-us-china-amount-citizens. 